\title{
Densitas Gizi dan Morbiditas serta Hubungannya dengan Status Gizi Anak Usia Prasekolah Pedesaan
}

\section{Nutrient Density and Morbidity and its Relationship with Nutritional Status of Preschool Children in Rural Areas}

\author{
Sarah Melati Davidson*, Cesilia Meti Dwiriani, Ali Khomsan \\ Departemen Gizi Masyarakat, Fakultas Ekologi Manusia, Institut Pertanian Bogor \\ (*smd.sarahmelati@gmail.com)
}

\begin{abstract}
ABSTRAK
Usia prasekolah merupakan periode golden age yang rentan terhadap penyakit infeksi sehingga harus diperhatikan pemenuhan gizinya agar dapat tumbuh kembang secara optimal. Tujuan penelitian ini adalah untuk mengkaji densitas zat gizi dan energi pangan, densitas asupan zat gizi dan energi, morbiditas, serta hubungannya dengan status gizi $\mathrm{BB} / \mathrm{U}, \mathrm{TB} / \mathrm{U}$, dan BB/TB pada anak usia prasekolah di daerah pedesaan. Penelitian ini menggunakan data Improving Child Growth and Development through Nutrition and Psychosocial Intervention in Early Childhood Education (PAUD) Setting in Rural Areas berkerja sama dengan Nestle Foundation (NF) Switzerland. Desain penelitian ini adalah cross-sectional study melibatkan 120 anak usia prasekolah usia 4-6 tahun. Lokasi dan subjek dipilih secara purposive dilakukan di Kecamatan Tamansari dan Kecamatan Dramaga, Kabupaten Bogor. Studi ini menemukan bahwa sebagian besar subjek memiliki status gizi yang baik. Densitas gizi pangan anak usia prasekolah pedesaan rendah kualitas zat gizinya. Densitas asupan zat gizi mikro ditemukan rendah tetapi tinggi densitas asupan energi. Lebih dari setengah subjek dengan tingkat morbiditas tinggi. Densitas asupan energi signifikan berhubungan dengan status gizi $\mathrm{BB} / \mathrm{U}$ dan $\mathrm{BB} / \mathrm{TB}(\mathrm{p}<0.05)$. Densitas asupan protein signifikan berhubungan dengan status gizi $\mathrm{BB} / \mathrm{U}$ dan $\mathrm{TB} / \mathrm{U}(\mathrm{p}<0.05)$. Morbiditas tidak signifikan berhubungan dengan status gizi.
\end{abstract} Kata kunci : Anak usia prasekolah, densitas gizi, morbiditas, status gizi

\section{ABSTRACT}

Preschool age is a golden age period that susceptible to infectious diseases and the nutritional need is very critical to reach optimum growth and development. The concept of nutrient density can be used to identify the quantity and quality of food consumption in the rural areas. The purpose of this study was to assess the nutrient and energy density food, nutrient and energy density intake, morbidity, and associations with nutritional status of WAZ, HAZ, and BAZ of preschool children in rural areas. This research uses the data from the research on Improving Child Growth and Development through Nutrition and Psychosocial Intervention in Early Childhood Education (PAUD) Setting in Rural Areas headed in collaboration with Nestle Foundation (NF) Switzerland. The study design was cross-sectional with total subjects 120 preschool children around 4-6 years old.. Locations and subjects were selected purposively located in Tamansari Subdistrict and Dramaga Subdistrict, Bogor District. This study found that most of the subjects had good nutritional status. The nutrient density food of preschool children had low. The quality of micronutrient density intake had low but high in energy density. More than half of subjects with high morbidity. Energy density intake positively significant related to WAZ and BAZ nutritional status $(p<0,05)$. Protein density intake was found positively significant related to WAZ and $H A Z(p<0,05)$. Morbidity was not correlated to nutritional status ( $p>0,05)$.

Keywords : Morbidity, nutrient density, nutritional status, preschool children 


\section{PENDAHULUAN}

Usia prasekolah disebut sebagai periode golden age dalam pertumbuhan dan perkembangan merupakan periode kritis yang membutuhkan makanan dengan kuantitas dan kualitas yang lebih baik dibandingkan orang dewasa. Anak usia prasekolah rawan mengalami gangguan gizi dan infeksi penyakit. Usia prasekolah lebih berisiko mengalami masalah gizi dibanding anak usia sekolah. ${ }^{1}$ Asupan gizi pada anak usia prasekolah sangat penting karena merupakan fondasi untuk kesehatan jangka panjang, juga kekuatan dan kemampuan perkembangan intelektualnya. Apabila pada masa tersebut pertumbuhan dan perkembangan seorang anak berjalan secara optimal diharapkan pada masa dewasa akan tumbuh menjadi manusia yang berkualitas. ${ }^{2,3}$

Hasil Riset Kesehatan Dasar (Riskesdas) 2013 menunjukkan prevalensi underweight pada anak berusia di bawah lima tahun adalah $19,6 \%$; prevalensi wasting sebesar $12,1 \%$ dan prevalensi stunting adalah $37,2 \% .{ }^{4}$ Masalah gizi stunting dan underweight lebih tinggi terjadi pada daerah pedesaan dibanding daerah perkotaan. ${ }^{5}$ Faktor timbulnya masalah gizi pada anak usia prasekolah dapat dipengaruh oleh beberapa faktor, baik secara langsung maupun tidak langsung. Masalah gizi secara langsung dipengaruhi oleh asupan yang tidak seimbang dan penyakit infeksi yang menyertai.

Salah satu masalah kesehatan yang penting terutama bagi anak anak-anak dalam masa tumbuh kembangnya adalah angka kesakitan (morbiditas) karena pada usia ini anak rentan terserang penyakit. Penyakit infeksi mempunyai kontribusi pada penurunan nafsu makan dan absorpsi zat gizi di dalam tubuh. Asupan gizi dimanfaatkan untuk proses penyembuhan penyakit infeksi akibatnya anak mengalami kekurangan zat gizi untuk menunjang pertumbuhan dan perkembangannya. Buruknya status gizi juga menyebabkan kondisi daya tahan tubuh menurun dan mudah terserang penyakit. Daya tahan tubuh meningkat bila keadaan gizi baik dan sebaliknya. Semakin tinggi angka morbiditas maka status gizi akan semakin menurun. ${ }^{6}$ Penelitian terdahulu menemukan underweight akan menyebabkan ISPA sebesar 29.91 kali lebih tinggi dibandingkan dengan anak yang status gizinya normal. ${ }^{7}$ Penelitian lain menyatakan bahwa penyakit infeksi seperti penyakit diare signifikan berhubungan dengan masalah gizi stunting. ${ }^{8,9}$

Presentase pengeluaran pangan di Indonesia untuk daerah perdesaaan masih lebih besar jika dibandingkan pengeluaran non-pangan, yang menunjukkan bahwa tingkat kesejahteraan rumah tangga di pedesaan masih lebih rendah dibandingkan di perkotaan..$^{10}$ The Nutrient Rich Food Index (NRF) atau yang disebut densitas zat gizi pangan merupakan instrumen yang dikembangkan oleh Drewnowski pada tahun 2010 untuk mengidentifikasi total energi dan komposisi zat gizi suatu pangan sehingga dapat dijadikan pedoman pemilihan pangan. ${ }^{11,12}$ Berdasarkan konsep densitas zat gizi pangan, selanjutnya dikembangkan pula konsep densitas asupan zat gizi yang digunakan untuk mengetahui jumlah asupan zat gizi dari pangan yang sebaiknya dibatasi konsumsinya untuk meningkatkan kualitas kesehatan. Selain itu, konsep densitas asupan zat gizi digunakan juga untuk mengidentifikasi kuantitas serta kualitas asupan zat-zat gizi dari pangan yang biasa dikonsumsi oleh masyarakat pedesaan. Konsep densitas gizi dapat diaplikasikan dalam kehidupan sehari-hari untuk memilih pangan dengan jumlah yang tepat sesuai dengan prinsip gizi seimbang. ${ }^{12,13}$ Tujuan dari penelitian ini adalah untuk mengkaji densitas zat gizi dan energi pangan, densitas asupan zat gizi dan energi, morbiditas, serta hubungannya dengan status gizi anak usia prasekolah pedesaan.

\section{BAHAN DAN METODE}

Penelitian menggunakan desain cross sectional study yang dilaksanakan pada bulan Desember 2017-Maret 2018. Lokasi dan subjek penelitian dipilih secara purposive bertempat pada 10 sekolah Pendidikan Anak Usia Dini (PAUD) di Kecamatan Tamansari dan Kecamatan Dramaga, Kabupaten Bogor. Subjek dalam penelitian ini berjumlah 120 anak berdasarkan kriteria: 1) berusia 4-6 tahun; 2) mempunyai orang tua lengkap dan bersedia berpartisipasi dalam penelitian; 3) tidak mempunyai cacat atau kelainan bawaan. Penelitian menggunakan data sekunder dari data penelitian Improving Child Growth and Development through Nutrition and Psychosocial Intervention in Early Childhood Education (PAUD) Setting in Rural Areas kerja sama Departemen Gizi Masyarakat Ilmu Keluarga dan Konsumen Institut Pertanian Bogor dengan Nestle Foundation (NF) 
Switzerland dan telah mendapat persetujuan etik dari Komisi Etik Penelitian Kesehatan Fakultas Kesehatan Masyarakat Universitas Diponegoro No.83/EC/FKM/2017. Data sekunder yang dikumpulkan meliputi data karakteristik subjek, karakteristik keluarga, konsumsi pangan berupa repeated 24 hours food recall, antropometri dan riwayat penyakit satu bulan terakhir.

Metode yang digunakan untuk menentukan densitas zat gizi pangan adalah Nutrient Rich Food Index (NRF 9,3) berdasarkan jumlah persentase daily value 9 jenis zat gizi yaitu protein, serat, vitamin A, vitamin $\mathrm{C}$, vitamin $\mathrm{E}$, kalsium $(\mathrm{Ca})$, zat besi $(\mathrm{Fe})$, magnesium $(\mathrm{Mg})$, dan kalium $(\mathrm{K})$ dan membatasi konsumsi 3 jenis zat gizi yaitu gula tambahan, asam lemak jenuh, dan natrium dengan semua daily value dihitung per 1000 kkal. ${ }^{11,14}$ Nilai atau skor densitas energi pangan dihitung menggunakan metode Dietary Energy Density (DED) ${ }^{15}$ Densitas asupan zat gizi (DG) dihitung berdasarkan perbandingan asupan zat gizi dengan asupan energi dan diklasifikasikan berdasarkan standar dari FAO. Densitas asupan protein memiliki tiga pengategorian menurut standar FAO. ${ }^{16}$ Densitas energi dihitung dengan membagi asupan energi dalam sehari dengan total berat pangan yang dikonsumsi dalam sehari. ${ }^{17}$ Morbiditas diukur berdasarkan hasil perkalian frekuensi jenis penyakit dengan lama (hari) penyakit diderita. Pengolahan data dilakukan dengan menggunakan Microsoft Excel 2013 dan SPSS versi 21.0. Analisis univariat dilakukan secara deksriptif untuk menggambarkan sebaran variabel yang diteliti berdasarkan persen dan rataan. Analsis bivariat dengan uji korelasi pearson/spearman dilakukan untuk melihat korelasi morbiditas dan densitas gizi dengan status gizi. Uji normalitas menggunakan Kolmogorov Smirnov dilakukan sebelum melakukan analisis bivariat. Bila data terdistribusi normal digunakan uji pearson namun bila data tidak terdistribusi normal digunakan uji spearman.

\section{HASIL}

Hasil penelitian ini menunjukkan $6,7 \%$ subjek lahir dengan berat yang rendah $(<2500 \mathrm{~g})$ dan sebanyak $93,3 \%$ subjek lahir dengan berat badan normal $(\geq 2500 \mathrm{~g})$. Jumlah subjek laki-laki dan perempuan dalam penelitian ini relatif seimbang. Lama pendidikan ayah dan ibu memiliki persentase yang sama, yaitu $66,7 \%$ tidak menamatkan SMA dan sisanya menamatkan SMA. Sebagain besar pekerjaan ayah subjek adalah buruh, yaitu

Tabel 1. Skor Dietary Energy Density (DED) dan Nutrient Rich Food (NRF) 9.3 Value

\begin{tabular}{|c|c|c|}
\hline Jenis Pangan & DED (kkal/g) & NRF 9.3/1000 kkal \\
\hline Pangan sumber karbohidrat $(\mathrm{n}=15)$ & 2,64 & 0,79 \\
\hline Daging, unggas, dan ikan $(\mathrm{n}=14)$ & 2,51 & 2,79 \\
\hline Telur $(n=3)$ & 2,49 & 2,63 \\
\hline Susu dan produk olahan $(n=5)$ & 3,43 & 3,51 \\
\hline Pangan nabati $(\mathrm{n}=5)$ & 2,08 & 4,48 \\
\hline Sayuran daun $(n=9)$ & 0,42 & 17,33 \\
\hline Sayuran buah $(n=6)$ & 0,32 & 21,15 \\
\hline Buah-buahan (n=11) & 0,63 & 12,61 \\
\hline Snack/jajanan $(\mathrm{n}=27)$ & 3,55 & 0,23 \\
\hline Pangan lainnya $(n=3)$ & 2,73 & 2,67 \\
\hline Lemak/minyak $(\mathrm{n}=3)$ & 5,83 & $-2,87$ \\
\hline
\end{tabular}

Tabel 2. Rata-Rata Densitas Asupan Zat Gizi Anak Usia Prasekolah

\begin{tabular}{lcc}
\hline \multicolumn{1}{c}{ Densitas Asupan Zat Gizi } & $\begin{array}{c}\text { Standar Densitas Gizi } \\
\text { Berdasarkan FAO }\end{array}$ & Rata-rata \pm SD \\
\hline Protein g/1000 kkal & $20-40$ & $24,64 \pm 6,12$ \\
Kalsium mg/1000 kkal & $500-800$ & $388,13 \pm 210,78$ \\
Zat Besi mg/1000 kkal & $7-40$ & $3,69 \pm 2,66$ \\
Vitamin A mcg/ 1000 kkal & $210-300$ & $124,94 \pm 86,42$ \\
Vitamin C mg/1000 kkal & $50-60$ & $25,36 \pm 18,76$ \\
& & \\
\hline
\end{tabular}




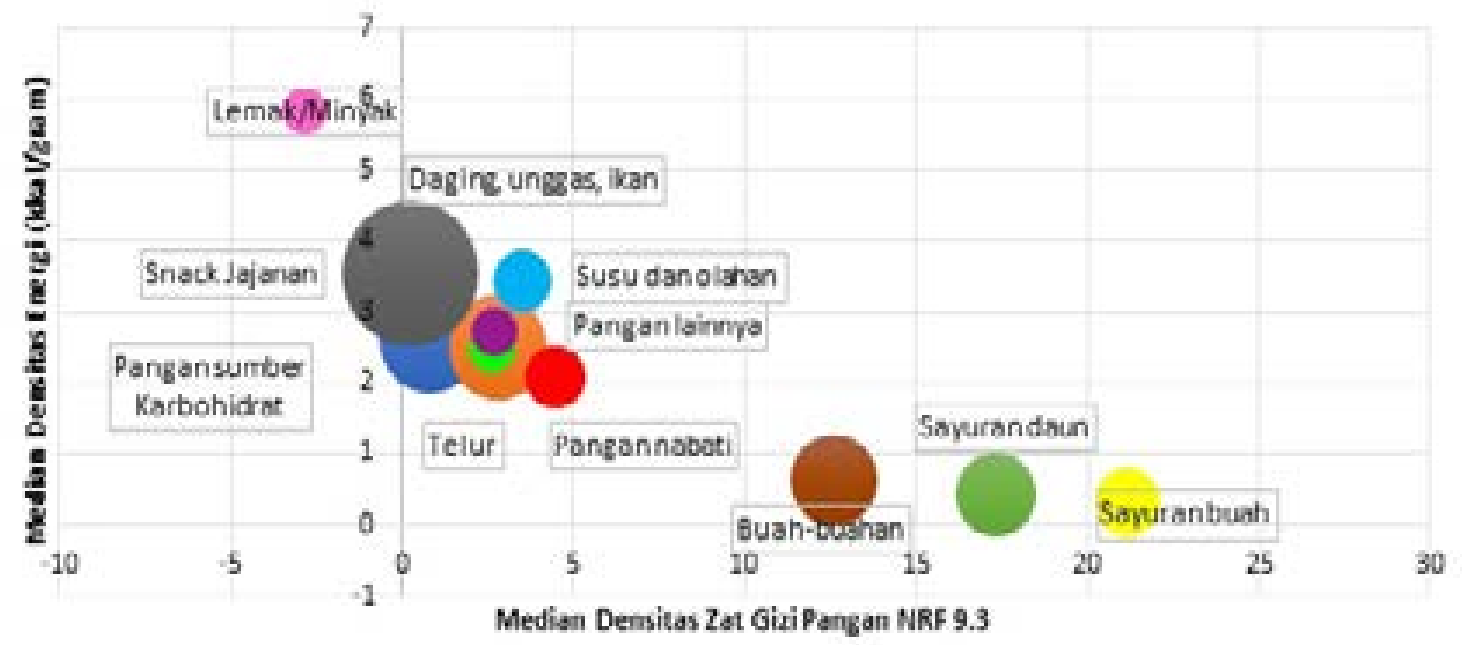

\section{Gambar 1. Sebaran Kualitas Zat Gizi Pangan Berdasarkaan Median Densitas Energi dan Zat Gizi Pangan}

sebanyak $70,8 \%$. Selain itu, sebagian besar subjek memiliki ibu yang bekerja, yaitu sebanyak $63,3 \%$. Persentase subjek yang berada di keluarga miskin berdasarkan garis kemiskinan Kabupaten Bogor BPS tahun 2015 adalah 7,5\%. Sebanyak 62,5\% subjek hidup dalam keluarga kecil ( $\leq 4$ orang), $33,3 \%$ keluarga sedang (4-6 orang) dan 4,2\% keluarga besar ( $\geq 7$ orang)

Status gizi anak dinilai dari pengukuran tinggi dan berat badan. Tinggi badan terendah yang ditemukan yaitu $97,10 \mathrm{~cm}$, sedangkan tertinggi yaitu 119, 40 dengan rata-rata 107,25 $\pm 5,13$ $\mathrm{cm}$. Berat badan terendah yang ditemukan, yaitu $13,20 \mathrm{~kg}$, sedangkan tertinggi yaitu $30,80 \mathrm{~kg}$ dengan rata-rata $17,22 \pm 3,02 \mathrm{~kg}$. Berdasarkan indeks BB/U sebanyak 19,2\% subjek underweight, $78,3 \%$ memiliki status gizi normal serta 2,5\% overweight. Berdasarkan indeks $\mathrm{TB} / \mathrm{U}$, penelitian ini menemukan sebanyak $24,2 \%$ subjek stunting dan 75,8\% normal. Dengan menggunakan indeks BB/TB sebanyak 5,9\% wasting, 90,8\% normal, dan gemuk sebanyak 3,3\%.

Nilai densitas energi pangan akan dibandingkan dengan nilai densitas gizi pangan tersebut. Perbandingan nilai densitas energi dan gizi pangan dari masing-masing kelompok bahan pangan dapat menjadi informasi penting terkait jenis pangan yang tidak hanya padat energi namun juga padat zat gizi. Nilai densitas energi pangan tertinggi diketahui pada penelitian ini terdapat pada kelompok lemak/minyak, snack/jajanan, serta susu dan produk olahannya. Kelompok pangan lemak/ minyak memiliki nilai densitas energi 5,83 kkal/g yang berarti pangan tersebut sangat tinggi densitas energi. Kelompok pangan lemak/minyak memiliki nilai NRF -2,87 per 1000 kkal. Nilai densitas gizi pangan di bawah 1 menunjukkan kualitas gizi yang sangat rendah dari bahan pangan tersebut. Kelompok pangan dengan densitas zat gizi tertinggi berdasarkan NRF 9,3 berturut-turut adalah sayuran buah, sayuran daun, serta buah-buahan. Sayuran buah diketahui memiliki nilai densitas energi sebesar $0,32 \mathrm{kkal} / \mathrm{g}$ yang menunjukkan pada nilai dengan densitas energi yang sangat rendah namun sangat tinggi kualitas gizinya dibuktikan dengan nilai NRF 9,3 sebesar 21,15 per 1000 kkal. Nilai Median skor densitas energi dan zat gizi pangan dapat dilihat pada Tabel 1 dan Gambar 1 . Penelitian terdahulu menemukan bahwa kualitas konsumsi yang baik berkaitan dengan tingginya konsumsi buah dan sayur yang memiliki densitas energi rendah yang dapat memenuhi kebutuhan zat gizi mikro secara tepat. ${ }^{18}$

Gambar 1 menjelaskan bahwa semakin besar nilai median densitas zat gizi pangan pada sumbu-X dan semakin rendah nilai median densitas energi pangan pada sumbu-Y maka semakin baik kualitas gizi pangan tersebut. Skor densitas zat gizi pangan tersebut, dapat juga digunakan sebagai pedoman dalam memilih makanan sesuai 
dengan kebutuhan gizi menurut umur dan juga menurut ada tidaknya suatu pantangan terhadap zat gizi tertentu sehingga dapat meningkatkan status gizi serta status kesehatan masyarakat. ${ }^{19}$ Berbagai model NRF mendapatkan hasil yang sama dengan penelitian terdahulu dan menyimpulkan bahwa semakin banyak zat gizi esensial yang dimasukkan ke dalam model, maka hubungannya dengan densitas energi semakin lemah..$^{9,10}$ Ukuran lingkaran pada gambar menunjukkan tingkat keragaman jenis pangan. Berdasakan gambar 1 diketahui snack/ jajanan merupakan kelompok pangan dengan tingkat keragaman tertinggi yang menunjukkan bahwa pemenuhan gizi anak banyak bersumber dari snack/jajanan yang dikonsumsi.

Rata-rata densitas asupan zat gizi protein subjek dibandingkan dengan standar FAO dapat dikategorikan cukup yaitu 24,64 $\pm 6,12 \mathrm{~g} / 1000 \mathrm{ka}-$ lori. Densitas asupan kalsium, zat besi, vitamin A maupun vitamin $\mathrm{C}$ diketahui secara berturut-turut sebesar 388,13 $\pm 210 \mathrm{mg} / 1000$ kalori, 3,69 $\pm 2,66$ $\mathrm{mg} / 1000$ kalori, $124,94 \pm 86,42 \mathrm{mcg} / 1000$ kalori dan $25,36 \pm 18,7 \mathrm{mg} / 1000$ kalori (Tabel 2). Ratarata densitas asupan energi adalah $2 \pm 0,38$ dengan nilai terendah 1,14 dan tertinggi 3,23 . Sebanyak $41,7 \%$ subjek dengan densitas asupan energi yang tinggi. Densitas asupan energi subjek yang rendah diketahui sebanyak $20,8 \%$ dan cukup yaitu $37,5 \%$. Tingginya densitas asupan energi namun masih kurang densitas asupan zat gizi mikro menunjukkan kualitas konsumsi pangan anak usia prasekolah yang rendah (Tabel 3).

Berdasarkan Tabel 4 diketahui empat jenis peyakit yang paling banyak diderita adalah flu, demam, ISPA, dan diare. Dengan rata-rata \pm SD lama sakit diderita yaitu flu 4,76 $\pm 2,35$ atau 4-5 hari, demam 3,72 $\pm 3,32$ atau 3-4 hari, ISPA 5,57 $\pm 3,32$ atau 5-6 hari, dan diare $1,82 \pm 0,81$ atau 1-2 hari. Rata-rata skor morbiditas adalah $8,3 \pm 7,3$. Sebanyak $47,5 \%$ dengan morbiditas rendah dan $52,5 \%$ dengan morbiditas tinggi. Penyakit ISPA dan diare pada anak signifikan berhubungan dengan status gizi. $^{7-9}$

Hasil uji korelasi dalam penelitian ini ditemukan bahwa densitas asupan energi signifikan berhubungan dengan status gizi $\mathrm{BB} / \mathrm{U}(\mathrm{p}=0,043$; $\mathrm{r}=0,185) \quad$ dan status gizi $\mathrm{BB} / \mathrm{TB} \quad(\mathrm{p}=0,005$; $\mathrm{r}=0,254)$. Semakin tinggi densitas asupan energi seseorang maka nilai $z$-score status gizi $\mathrm{BB} / \mathrm{U}$ dan BB/TB akan semakin meningkat. Densitas asupan energi tidak signifkan berhubungan dengan status gizi $\mathrm{TB} / \mathrm{U}(\mathrm{p}=0,956 ; \mathrm{r}=0,005)$. Densitas asupan

Tabel 3. Nilai Minimum, Maksimum, Rata-Rata Densitas Energi Asupan dan Sebaran Anak Berdasarkan Kategori Tingkat Densitas Energi Asupan

\begin{tabular}{lc}
\hline \multicolumn{1}{c}{ Densitas Energi } & Besaran \\
\hline Densitas Energi Asupan (kkal/g) & \\
Minimum & 1,14 \\
Maksimum & 3,23 \\
Rata-rata \pm SD & $2,00 \pm 0,38$ \\
Kategori tingkat densitas energi konsumsi n(\%) & \\
Rendah $(\mathrm{kkal} / \mathrm{g})$ & $25(20,8)$ \\
Cukup $(\mathrm{kkal} / \mathrm{g})$ & $45(37,5)$ \\
Tinggi $(\mathrm{kkal} / \mathrm{g})$ & $50(41,7)$ \\
\hline
\end{tabular}

Tabel 4. Jenis Penyakit, Skor Morbiditas, serta Rata-Rata Lama Sakit Diderita

\begin{tabular}{lc}
\hline Lama Sakit & Rata-Rata Lama Sakit (hari) \\
\hline Flu & $4,76 \pm 2,35$ \\
Demam & $3,72 \pm 3,32$ \\
ISPA & $5,57 \pm 3,32$ \\
Diare & $1,82 \pm 0,81$ \\
\hline Skor Morbiditas (n(\%)) & Besaran \\
\hline Rendah (<Median) & $57(47,5)$ \\
Tinggi ( $\geq$ Median) & $63(52,5)$ \\
Median (Min-Max) & $8(0-25)$ \\
\hline
\end{tabular}


protein signifikan berhubungan dengan status gizi $\mathrm{TB} / \mathrm{U}(\mathrm{p}=0,000 ; \mathrm{r}=0,354)$ dan status gizi $\mathrm{BB} / \mathrm{U}$ $(p=0.000 ; r=0,378)$, tetapi tidak signifikan berhubungan dengan status gizi $\mathrm{BB} / \mathrm{TB}(\mathrm{p}=0,505$; $\mathrm{r}=0,061$ ). Semakin tinggi densitas asupan protein maka status gizi $\mathrm{TB} / \mathrm{U}$ dan $\mathrm{BB} / \mathrm{U}$ anak semakin baik. Tidak dilakukan uji korelasi antara densitas asupan zat mikro kalsium, zat besi, vitamin $\mathrm{A}$, dan vitamin $\mathrm{C}$ dengan status dikarenakan rendahnya kualitas densitas asupan zat gizi mikro. Morbiditas tidak signifikan berhubungan dengan status gizi $\mathrm{BB} / \mathrm{U}, \mathrm{TB} / \mathrm{U}$, dan $\mathrm{BB} / \mathrm{TB}(\mathrm{p}>0,05)$.

\section{PEMBAHASAN}

Konsep densitas asupan zat gizi di daerah pedesaan umumnya dikembangkan untuk menganalisis pola konsumsi pangan di daerah pedesaan serta pengaruhnya terhadap kejadian masalah gizi yang terdapat di daerah tersebut. Selain itu, konsep densitas asupan zat gizi digunakan juga untuk mengidentifikasi kuantitas serta kualitas asupan zat-zat gizi dari pangan yang umum dikonsumsi oleh masyarakat pedesaan. ${ }^{11}$ Selain itu, konsep densitas asupan zat gizi merupakan keseimbangan kompisisi zat gizi yang diperoleh dari pangan yang dikonsumsi yang memberikan manfaat bagi tubuh yaitu pertumbuhan untuk masa anak-anak serta manfaat kesehatan dan penurunan risiko penyakit untuk usia dewasa. ${ }^{19}$ Hasil penelitian ini selaras dengan penelitian terdahulu bahwa skor NRF tertinggi adalah pangan dengan densitas energi yang rendah, yaitu sayur daun, sayuran buah serta buah-buahan. Pada penelitian tersebut kelompok pangan yang tinggi kualitas zat gizinya adalah sayuran buah, sayuran daun, serta buah-buahan. Minyak, biji-bijian, dan makanan manis/asin seperti gorengan maupun snack/jajanan memiliki densitas energi yang tinggi, tetapi rendah kandungan zat gizi per kalorinya. ${ }^{11,14,18,20}$ Umumnya jenis pangan tersebut mengandung densitas zat gizi mikro yang rendah dibandingkan dengan pangan yang mengandung gula alami. Densitas energi pangan berkisar antara 0 sampai dengan 9 $\mathrm{kkal} / \mathrm{g}$ dipengaruhi oleh komposisi zat gizi makro dan kadar air. Kadar air merupakan pengaruh yang paling besar karena air menambah berat makanan tanpa menyumbangkan energi. ${ }^{20}$

Hasil penelitian ini memberi informasi bahwa proses pengelohan mempengaruhi nilai densi- tas gizi dan energi pangan tersebut. Bahan pangan yang sama dengan proses pengolahan secara berbeda akan memiliki nilai densitas energi dan densitas zat gizi yang berbeda. Diketahui dalam penelitian ini proses pengolahan dengan menggoreng akan meningkatkan nilai densitas energi dan menurunkan nilai densitas zat gizinya. Kelompok sayuran buah, sayuran daun, dan buah-buahan merupakan kelompok pangan yang dikonsumsi tanpa melalui proses penggorengan sehingga tidak memberi kenaikan nilai pada zat gizi yang dibatasi konsumsinya. Bahan pangan tersebut pada umumnya dimakan langsung atau melalui proses pengolahan dengan merebus/kukus. Salah satu kelompok pangan dengan kualitas densitas gizi pangan yang rendah dengan densitas energi tinggi adalah snack/ jajanan. Menurut Shriver et al., tahun 2017 mengonsumsi snack terutama pada anak berkontribusi besar sebanyak $44 \%$ pada asupan natrium, $52 \%$ total fat dan $53 \%$ gula tambahan. Ketiga zat gizi ini merupakan zat gizi yang dibatasi menurut NRF 9,3. ${ }^{21}$ Konsumsi energi, gula dan lemak jenuh yang berlebih, tetapi rendah konsumsi buah dan sayur dapat menunjukkan kualitas konsumsi pangan yang rendah. Tidak terpenuhinya kebutuhan gizi baik gizi makro maupun gizi mikro akan menyebabkan growth faltering. Pertumbuhan tinggi badan dapat terhambat bila seseorang mengalami defisiensi protein. Meskipun konsumsi energi cukup, tetapi rendah asupan protein hewani dan zat gizi mikro dalam jangka waktu yang lama disebut sebagai faktor risiko stunting anak..$^{22,23}$

Temuan kualitas densitas asupan zat gizi mikro pada penelitian ini sejalan dengan penelitian terdahulu yang menemukan bahwa pada daerah pedesaan densitas asupan kalisum, zat besi, vitamin $\mathrm{A}$, dan vitamin $\mathrm{C}$ masih rendah. ${ }^{12,20}$ Rendahnya densitas asupan zat gizi mikro pada anak usia prasekolah dapat disebabkan karena tingginya konsumsi snack/jajanan dan pangan yang lain yang padat energi, tetapi rendah kualitas zat gizi mikronya. Sejalan dengan hasil penelitian Prasetyo et al., tahun 2013 yang menemukan sebagian besar anak usia 2-6 tahun memiliki kualitas konsumsi pangan rendah terutama zat gizi mikro. ${ }^{24}$ Anak usia prasekolah seharusnya telah mengonsumsi pangan dengan jumlah yang tepat sesuai dengan prinsip gizi seimbang sehingga dapat bertumbuh kembang secara optimal. Zat gizi mikro 
sangat diperlukan terutama oleh anak untuk proses tumbuh kembang dan peningkatan daya tahan tubuh agar tidak mudah terserang infeksi penyakit.

Densitas gizi yang diuji hubungannya dengan status gizi pada penelilitian ini adalah densitas asupan energi dan densitas asupan protein dengan asumsi bahwa hanya densitas asupan yang adekuat yang akan diuji. Selain itu, penelitian terdahulu menemukan bahwa densitas asupan zat gizi yaitu zat besi, vitamin A dan vitamin C ditemukan tidak berhubungan dengan status gizi. ${ }^{19,20}$ Densitas asupan energi signfikan berhubungan dengan status gizi $\mathrm{BB} / \mathrm{U}$ dan status gizi $\mathrm{BB} / \mathrm{TB}(\mathrm{p}<0,05)$. Hasil penelitian ini telah sejalan dengan penelitian Rolls tahun 2006 yang menemukan bahwa terdapat hubungan yang positif antara densitas energi konsumsi yang tinggi dengan berat badan pada anak usia 2-8 tahun. ${ }^{25} \mathrm{Hal}$ ini dikarenakan berat badan merupakan parameter yang sensitif pada perubahan yang terjadi dalam waktu yang relatif singkat seperti asupan energi. Semakin banyak asupan energi akan semakin meningkat berat badan. ${ }^{26}$ Oleh karena itu, densitas asupan energi sering dikaitkan dengan kejadian obesitas. Ekaningrum et al. tahun 2016 menemukan bahwa densitas asupan energi tidak berhubungan secara signifikan dengan status gizi, tetapi memiliki korelasi positif yang cukup kuat antara keduanya $(\mathrm{p}=0,607, \mathrm{r}=0,402) .{ }^{20}$ Hasil penelitian ini juga menemukan densitas asupan protein signifikan berhubungan dengan status gizi $\mathrm{BB} / \mathrm{U}$ dan $\mathrm{TB} / \mathrm{U}(\mathrm{p}<0,05)$. Temuan ini sejalan dengan penelitian terdahulu yang menyatakan bahwa asupan protein berhubungan dengan masalah gizi underweight dan stunting. ${ }^{26,27}$ Protein dibutuhkan untuk membangun, menjaga, dan memperbaiki jaringan tubuh. Selain itu, protein juga berperan penting dalam pertumbuhan. Defisiensi energi dan protein secara progresif menyebabkan kerusakan mukosa, menurunnya resisten terhadap kolonisasi dan invasi kuman patogen. Menurunnya imunitas dan kerusakan mukosa memegang peranan utama dalam mekanisme pertahanan tubuh, sehingga pada akhirnya akan mempengaruhi insiden penyakit. $^{27}$

Morbiditas dan status gizi saling memengaruhi. Status gizi pada anak di bawah lima tahun merupakan dasar dari tingginya morbiditas. Status gizi yang kurang baik akan menyebabkan daya tahan tubuh menurun dan mudah terserang penya- kit infeksi. Begitupun sebaliknya bahwa terserang penyakit infeksi mengganggu metabolisme zat-zat gizi di dalam tubuh sehingga pemanfaatan zat gizi di dalam tubuh menjadi tidak optimal dan akan berdampak pertumbuhan. ${ }^{28,29}$ Pada penelitian ini, morbiditas ditemukan tidak berhubungan dengan status gizi $(p>0,05)$. Hasil yang sama juga ditemukan oleh Elvandari tahun 2017 dalam penilaian status gizi anak usia 1-3 tahun di Jawa Tengah. Hal ini dapat disebabkan oleh faktor lingkungan seperti cuaca yang mempengaruhi kesehatan anak. Cuaca yang tidak menentu menyebabkan daya tahan tubuh seseorang menjadi turun sehingga mudah sekali terserang penyakit terutama anak-anak. Anak-anak dalam masa pertumbuhan dan perkembangannya mempunyai organ tubuh yang masih lemah dengan sistem imunitas yang masih rentan terhadap gangguan dari lingkungan. Selain itu, perilaku hidup bersih dan sehat juga menjadi faktor pengaruh morbiditas dan status gizi anak..$^{26,28,30}$

\section{KESIMPULAN DAN SARAN}

Densitas gizi pangan anak usia prasekolah pedesaan masih rendah kualitas zat gizinya. Lebih dari setengah subjek dengan tingkat morbiditas tinggi. Densitas asupan energi signifikan berhubungan dengan status gizi $\mathrm{BB} / \mathrm{U}$ dan $\mathrm{BB} / \mathrm{TB}$. Densitas asupan protein signifikan berhubungan dengan status gizi $\mathrm{BB} / \mathrm{U}$ dan $\mathrm{TB} / \mathrm{U}$. Morbiditas tidak signifikan berhubungan dengan status gizi.

Peneliti lain dapat melakukan analisis densitas gizi lebih lanjut dengan memperhitungkan harga pangan lokal maupun non-lokal daerah setempat. Diperlukan program intervensi berupa edukasi gizi agar orang tua dapat selektif dalam memilih makanan bagi anak dan menurunkan kualitas konsumsi snack/jajanan yang kurang bergizi dan meningkatkan konsumsi sayur, buah, serta pangan hewani yang kaya akan zat gizi mikro dengan memanfaatkan pangan lokal maupun non-lokal.

\section{UCAPAN TERIMA KASIH}

Penulis mengucapkan terima kasih kepada The Nestle Foundation Switzerland yang telah mendanai penelitian ini.

\section{DAFTAR PUSTAKA}

1. Bisai S, Mallick C. Prevalence of Undernutrition Among Kora-Mudi Children Aged 2-13 
Years in Paschim Medinipur District, West Bengal, India. World J Pediatr. 2011 Feb;7(1): 31-36.

2. Vinod N, Swarnakanta L, Smita P, Pushpa D. Nutritional Status and Dietary Pattern of Underfive Children in Urban Slum Area. Nat J Comm Med. 2(1):143-48.

3. Tapiwa CR, Blessing K, More M, et al. Analysis of Trends in Nutritional Status and Morbidity of Under-Fives Among Internally Displaced Persons at Chingwizi, Mwenezi District, Zimbabwe 2014-2015. International J Innovative Research \& Development. 2017 May; 6(5):117-25.

4. Kemenkes RI. Laporan Nasional Hasil Riset Kesehatan Dasar 2013. Jakarta : Kementerian Kesehatan RI; 2013.

5. Rachmi CN, Agho KE, Li M, Baur LA. Stunting, Underweight and Overweight in Children Aged 2.0-4.9 Years in Indonesia Prevalence Trends and Associated Risk Factors. PLos ONE 2016 May; 11(5):1-17.

6. Wirjatmadi, RB. Beberapa Faktor yang Berhubungan dengan status Gizi Balita Stunting. Indonesian J Public Health. 2012;8(3):99-104.

7. Nuryanto. Hubungan Status Gizi terhadap Terjadinya Penyakit Infeksi Saluran Pernafasan Akut (ISPA) pada Balita. Jurnal Pembangunan Manusia. 2012; 6(2):96-107.

8. El-Taguri A, Betilmal I, Mahmud SM, Ahmed AM, Goulet O, Galan P, Hercberg S. Risk Faktors for Stunting Among Under-Fives in Libya. Public Health Nutrition. 2007; 12(8):11411149.

9. Teshome B, Kogi-Makau W, Getahun Z, Taye G. Magnitude and Determinants of Stunting in Children Underfive Years of Age in Food Surplus Region of Ethiopia: The Case of West Gojam Zone. Ethiopian Journal Health Development. 2009; 23(2):98-106.

10. Wuryandari RD. Faktor-Faktor yang Mempengaruhi Pengeluaran Makanan, Pendidikan, dan Kesehatan Rumah Tangga Indonesia. Jurnal Kependudukan Indonesia. 2015 Juni;10(1):27-42.

11. Drewnowski A et al. 2010. The Nutrient Rich Foods Index Helps to Identify Healthy, Adorable Foods. Am J Clin Nutr 2010 Apr; 91(4) : 1095-1101.
12. Jayanti LD. Studi Aspek Sosial Ekonomi dan Budaya, Konsumsi Pangan, serta Densitas Gizi pada Masyarakat Kasepuhan Ciptagelar Jawa Barat. [Disertasi]. Bogor (ID): Institut Pertanian Bogor. 2014.

13. Drewnowski A, Keast DR, Fulgoni VL. Developmental and Validation of The Nutrient Rich Foods Index: A Tool To Measure Nutritional Quality Foods. J Nutr. 2009 Aug; 139(8):1549-54.

14. Drewnowski A, Fulgoni VL. Nutrient Density: Principle and Evaluation Tools. Am J Clin Nutr. 2014 May 99(suppl): 1223-8 .

15. Rolls BJ. The Relationship Between Dietary Energy Density and Energy Intake. Physiology \& Behavior. 2009;97:609-15.

16. Drewnowski A. Concept of A Nutritious Food: Toward A Nutrient Density Score. Am J Clin Nutr. 2005 Oktober; 82(4):721-32.

17. Ledikwe JH, Ello-Martin, Julia A, Rolls BJ. Portion Sizes and the Obesity Epidemic. J. Nutr. 2006;135(4):905-909.

18. Patterson E, Wärnberg J, Poortvliet E, Kearney JM, Sjöström M. Dietary Energy Density As A Marker of Dietary Quality in Swedish Children and Adolescents : The European Youth Heart Study. Eur J Clin Nutr. 2010 Apr; 64(4):356-63.

19. Vossenaar M, Solomons NW. The Concept of "Critical Nutrient Density" in Complementary Feeding: The Demands on The "Family Foods" For The Nutrient Adequacy of Young Guatemalan Children with Continued Breastfeeding. Am J Clin Nutr. 2012;(95):859-66.

20. Ekaningrum AY, Sukandar D, Martianto D. Keterkaitan Densitas Gizi, Harga Pangan, dan Status Gizi pada Anak Sekolah Dasar Negeri Pekayon 16 Pagi. J. Gizi Pangan. Juli 2017; 12(2):139-46.

21. Shriver LH, Marriage BJ, Bloch TD, et al. Contribution of Snacks to Dietary Intakes of Young Children in The United States. Matern Child Nutr. 2017;14(1):1-9.

22. Black RE et al. Maternal and Child Undernutrition: Global and Regional Exposures and Consequences. Lancet. 2008; 371(9608):24360.

23. Ramli A, Inder KE, Bowe KJ, Jacobs J, Dibley MJ. Prevalence and Risk Faktors for Stunting 
and Severe Stunting Among Under-fives in North Maluku Province of Indonesia. BMC Pediatr. 2009 Oct;6(9):64.

24. Prasetyo TJ, Hardinsyah, Sinaga T. Konsumsi Pangan dan Gizi serta Skor Pola Pangan Harapan (PPH) pada Anak Usia 2-6 Tahun di Indonesia. Jurnal Gizi dan Pangan. 2013;8(3): 159-166.

25. Rolls BJ, Ledikwe JH, Blanck MH, Khan LK, Serdula MK, Seymour JD, Tohill BC. Dietary Energy Density is Associated with Energy Intake and Weight Status in US adults. Am J Clin Nutr. 2006;83:1362-1368.

26. Rahim FK. Faktor Risiko Underweight Balita Umur 5-79 bulan. Jurnal Kesehatan Masyarakat. 2014 Januari;9(2):115-21.

27. Hayati AW, Hardinsyah, Jalal F. FaktorFaktor Risiko Stunting, Pola Konsumsi Pangan, Asupan Energi dan Zat Gizi Anak 0-23 Bulan. [Disertasi]. Bogor (ID): Institut Perta- nian Bogor. 2013.

28. Ngure FM, Reid BM, Humphrey JH, Mbuya MN, Pelto G, Stoltzfus RJ. 2014. Water, Sa- nitation, and Hygiene (WASH), Environmental Enteropathy, Nutrition, and Early Child Development: Making The Links. Annals of the New York Academy of Sciences. 2014;1308(1):118-128.

29. Haque MA, Haque MN, Sultana MM, Hossen SM, Paul S. Effect of Water Quality, Environmental Sanitation and Hygiene Practices on Health of School Going Children of Urban Slum Areas. J Env Sci Natural Res. 2015;8(1):115-119.

30. Elvandari M, Briawan D, Tanziha I. Hubungan Asupan Zat Gizi dan Serum Retinol dengan Morbiditas pada Anak 1-3 Tahun di Jawa Tengah. Jurnal Media Kesehatan Masyarakat Indonesia (MKMI). Desember 2016;12(4): 201-207. 